\title{
When Politics is more than Words: A Hermeneutic Analysis of Freudian Psychoanalytic Elements among selected Philippine Presidential State of the Nation Addresses (SONA)
}

\author{
Andrea Nicole Sy \\ Department of Political Science, \\ Faculty of Arts and Letters- \\ University of Santo Tomas Manila, Philippines \\ Mary Louise Beatrix Yson \\ Department of Political Science, \\ Faculty of Arts and Letters- \\ University of Santo Tomas Manila, Philippines \\ Nikolai Gavino \\ Department of Political Science, \\ Faculty of Arts and Letters- \\ University of Santo Tomas Manila, Philippines \\ Michael Warren De Leon \\ Department of Political Science, \\ Faculty of Arts and Letters- \\ University of Santo Tomas Manila, Philippines \\ Jonathan Ocampo \\ Department of Political Science, \\ Faculty of Arts and Letters- \\ University of Santo Tomas Manila, Philippines \\ Dr. Froilan C. Calilung \\ Department of Political Science, \\ Faculty of Arts and Letters- \\ University of Santo Tomas Manila, Philippines
}

The President's State of the Nation Address is a historical and a very important speech being delivered by an incumbent president annually which focuses on the plans, programs, and solutions a president would want to put on the table which he views beneficial for the people in addition to the accomplishments that have been carried out in the past year. In fact, the SONA, as it is more popularly termed in the Philippines, is also an opportune moment given for the sitting administration to boast about its achievements and accomplishments for the year and on how he plans to lead the country forward and hopefully provide a better future for the citizenry.

However, the SONA is not just about the plans, the projects, and the accomplishments of the sitting administration. In fact, this political event is a yearly gathering of the political elite 
wherein fashion and flare in terms of the wardrobe worn by the guests, the arrangement of the venue and even how the entire SONA is going to unfold also gets their fair share of the political spectacle sometimes in a dramatic fashion. Outside of the Batasan Complex which houses the Philippine House of Representatives and is the traditional venue of the speech, presidential opposition, activists and detractors also gather to air their grievances against the sitting President. The highlight of the event gravitates around the President and the speech he/ she is to deliver. The speech will be the focal point of praise and applause as well as scrutiny from the prying public eye.

But the SONA should be seen beyond mere words and rhetoric, as the gestures, mannerisms, and the body language the President displays while on the podium delivering his or her speech also deserves an all important analysis. While it is also true that the speeches have been analyzed from a political lens, no study has attempted to explain the gestures, bodily actions and mannerisms of these presidents and connect these to their individual leadership persona.

To wit, this paper focuses on the visible gestures, mannerisms, and body language of Philippine presidents that they showcased while they're delivering their respective State of the Nation Addresses and seeks to correlate it with their leadership styles. For this paper, the presidential SONAs of Former Pres. Gloria Macapagal-Arroyo, Immediate Past President Benigno Aquino III, and the current chief executive, President Rodrigo Roa Duterte were carefully and meaningfully analyzed in the attempt to see beyond the words contained in the speeches.

This paper is focused on how Sigmund Freud's Psychoanalytic theory can be manifested while basing only on the aforementioned presidents' body language while delivering their State of the Nation Address. As opined by Cherry (2019), Sigmund Freud is considered to be one of Psychology's most popular and influential thinkers of the $20^{\text {th }}$ century and that his great works, theories, and contributions made it easier for people to understand terms such as childhood, sexuality, memory, therapy, and personality. Sigmund Freud's contribution to the world has made head waves in every culture of the world wherein he was the one who introduced the terms, "Freudian slip", "repression", and the word "denial". Other than establishing new terms, Freud was also able to introduce concepts such as the unconscious mind, the id, ego, and superego. He was also instrumental in the establishment of theories such as life and death instincts, psychosexual development, mechanisms of defense, theory of culture, and the psychoanalytic theory.

\section{RESEARCH DESIGN}

The design that this study used corresponds to a Qualitative approach. The primary research technique that was utilized is Content Analysis through the use of Hermeneutics method. It is to be understood that content analysis is a research method for studying documents and communication artifacts, which might be texts of various formats as in the case of pictures, audio or video. As mentioned these interpretations were made through the use of Hermeneutics. This platform enabled the researchers to make interpretations and gain an indepth understanding of the researched phenomenon. This is based largely on the premise that Hermeneutic research emphasizes subjective interpretations in the research of meanings of texts, art, culture, social phenomena and thinking. The observation is based on hermeneutics analysis wherein the researchers studied the gestures of the three presidents, generated a systematic assessment about the findings, and relate to Sigmund Freud's psychoanalytical theory.

In effect, the researchers attempted to determine the gestures, mannerisms and actuations of the three presidents as they delivered their State of the Nation Addresses. The presidents 
included in the analysis are former Presidents Gloria Macapagal Arroyo, Benigno Aquino III, and current president President Rodrigo Duterte. This was done through ample use of recorded video clippings of their respective SONAs. Using Freudian psychoanalytical theory, the researchers aimed to carefully assess and provide ample meaning through a substantial discussion of what these gestures and actions mean with respect to the theory of psychoanalysis. The goal of the paper is to understand the political - psychological construct of the gestures, actions and mannerisms in which the speeches were delivered and how it relates to the political stance/ styles pertinent to the issues and events given the time that the said speeches were delivered.

This study is anchored on the following problems

\section{PROBLEM STATEMENT}

1. How are Freudian elements manifested in the gestures, actions and bodily movements of selected Philippine presidents in the delivery of their respective State of the Nation Addresses (SONA)?

2. How can various Psychoanalytic elements be used to interpret their political backgrounds, handling of political issues and leadership styles?

\section{FOCUS OF THE STUDY}

The paper focused on former Presidents Gloria Macapagal Arroyo, Benigno Aquino III, and the incumbent President Rodrigo Duterte. The researchers made ample use of their State of the Nation address in determining Freud's psychoanalysis / Freudian tendencies particularly from Arroyo's 2001-2009, Aquino 2010-2011, and Duterte 2016-2019.

The researchers chose their State of the Nation addresses for two reasons; it is apparent that in these speeches, their exposure is longer, and that they can be observed with greater scrutiny amidst the public eye. The researchers sought to determine the factors that affect their actions and gestures in front of the people in a grand stage as that of the SONA. The researchers analyzed these gestures, actuations and mannerisms in line with Freud's psychoanalysis theory. Sigmund Freud gained worldwide fame for his Psychoanalysis theory. In this theory Freud tends to unravel the different factors and experiences of man to prove a phenomenon. The theory of Psychoanalysis is suited in studying the actions and events of the Presidents during their respective terms. This study is relevant in as much as the intrinsic relationship between Political Science and Psychology was explored.

This relationship finds meaning especially in the concept of Id, Ego and Super Ego of Freud. These concepts perfectly explain nonetheless certain phenomenon or experience of an individual. Sigmund Freud thought of a way into explaining and having a conclusion towards an individual in relation to their actions and motivations (Bondi , 2007). First and foremost, the Id is explained by Freud as something that happens or done naturally by human beings. Secondly, the Ego is a measurement of mental or physical strength of a human being according to Freud. The ego is used by our mind on how we scale things that we are doing. Lastly, the Super Ego which according to Freud is the part of our mind that filters human actions towards morality and virtuousness.

\section{An Analysis of the 2002-2009 SONAs of Former President Gloria Macapagal Arroyo}

The State of the Nation Addresses of President Gloria Macapagal Arroyo in years 2002, 2004, 2005, 2006, 2007, 2008 and 2009 are the focus of interpretation in the first part of this hermeneutics paper. Due to the unavailability of the videos, the 2001 and 2003 SONA were not included in the analysis. Using Sigmund Freud's theories of the Unconscious Mind and the id, 
ego, and super-ego, the gestures and facial expressions President Arroyo made were interpreted.

The theory of the unconscious mind is about having an unconscious and conscious part of the mind with the former being the id and the latter being the ego (Solms, 2004). According to Bargh and Morsella (2008), being in the state of the unconscious mind means not being deliberate about the actions one is doing. President Arroyo's State of the Nation Address in year 2002 was very formal compared to the speeches nearing the half of her term and towards the end. In this 2002 speech, the lady President had "Freudian slips" which is one of the most known nonverbal behaviors. The dictionary terms it as a "slip of the tongue" that is driven by the subconscious part of the mind and can be used to further study the deeper mechanisms within one's power of reasoning and perception. The emotion of an individual while he or she is doing or experiencing something is also important, because it is plays a part in many of the nonverbal behaviors, one being the Freudian slip.

These so called "slips" mean that a person made a mistake in the word they were about to say. For example, the person might have wanted to say, "It's nice to see you today", but then ended up saying "It's sad to see you today". These Freudian slips can give a glimpse as to what the person might be subconsciously thinking or what his mind might be preoccupied about.

In the 2002 SONA, President Arroyo logged in three times wherein she made a blunder. The time stamps are 8:45, 12:01, 22:07. These can also be considered Freudian slips even if she didn't say a completely different word. The first instance was when the president was stating a quote from Jose Rizal and she left out the word "not", but then she suddenly closed her eyes and shook her head then immediately restated the quote. The second instance was when she was supposed to say "war against terrorism" but she ended up saying "war against terrorist" and did the same thing and immediately corrected herself. Lastly, she stumbled on the word "solidarity".

Those Freudian slips which President Arroyo had made and are most likely due to her unconscious mind can be contrasted to the joke she made nearing the end of her speech. In this regard, she was very much intentional with the joke she made. It was about her height since she is a woman of small stature. She mentioned how although she cannot grow taller but she can still definitely grow much more when it comes to improving her service to the public. She was smiling prior to saying the joke.

It is important to note that facial expressions play a huge part in determining what might be going on in a person's mind. This is because the facial expressions of a person show the emotion they have and of course this comes from their brain and mind (Adolphs, 2002). This explains why a few seconds before making the joke, the president was already smiling. President Arroyo smiled four times in the video. The time stamps are as follows: 14:04, 16:45, 25:00 - 25:10, 27:47 - 27:57. One of the reasons for her smiles was because of the joke she made, the other three times she smiled was because of the targets she had accomplished and she was proudly stating all of them. It can be assumed that in this SONA of 2002, the president was happy whenever she smiled. However, according to Ekman (1992), what the person is feeling may not be equivalent to happiness, even if they were smiling. Some people can actually use a smile to hide a weakness or pain that they are feeling. The race or gender of the person didn't matter regarding such things. It can be the same medium or facial expression but different emotions being felt or carried by the person. 
The gesture which President Arroyo had done the most was a slight nod every time she would put emphasis on certain words or phrases like "a Strong Republic". It was always accompanied by the raising of her eyebrows. The other is only a light nod. It can be assumed that in this SONA of 2002, the president was very controlled and disciplined and clearly manifests the ego.

The SONA of 2004 was more lively compared to the 2002 SONA and President Arroyo retained some similar gestures from the latter year's speech but new ones were added. According to Freud, there are three conditions in which a person's mind enters. One would be the conscious another is the preconscious, and lastly the unconscious (Ekstrom, 2004). In 14:34 she made a fist as a hand gesture to put emphasis on what she was saying. She did this twice the other was in the 44:45 of the video. Based on the theory of the unconscious mind, the actions, behavior, and what a person says or their "drive" is heavily influenced first by the memories in the unconscious state of the mind (Ekstrom, 2004).

From the SONA of 2002, the gestures which she still consistently did and are present in the SONA of 2004 are the raising of her eyebrows to give certain words emphasis which she did twice in 20:10 and 29:14. President Arroyo had more hand gestures in this speech than in 2002. She was more animated. She would raise both of her hands several times to put emphasis on some words and sometimes to point to the audience. Another consistent gesture she would do was to nod lightly to show emphasis again on certain words but also when she was speaking to certain groups of people in the audience. It has been said that nodding lightly helps in subconsciously making a person agree with the speaker and is Freudian in nature.

This 2004 SONA had more smiles from President Arroyo than the 2002 SONA. She smiled most during the latter part of the speech. She smiled four times in 39:00 - 39:50, 40:32, 40:45, and 45:02. The other smile which was from 40:45 - 41:09, the president burst out in laughter due to the long applause from the audience accompanied by a standing ovation due to the accomplishments achieved that year. The President also still made some Freudian slips from 32:54 and 25:56. From this 2004 SONA, it can be argued that expressions are learned by a person through the environment culture and society one grew up in. However, not all expressions are learned, for example, when a baby smiles or laughs due to the mother tickling the child (Ekstrom, 2004).

It is very hard to express emotions without gestures or facial expressions. After all, it is the starting point for understanding emotions and what might be going on in a person's mind (Russell, 2002). It is also one of the best ways to communicate both explicitly and implicitly one's feelings or emotions. The shortest SONA speech of President Arroyo would be the 2005 SONA lasting only for about twenty-eight minutes.

President Arroyo could not immediately start her speech because for more than a minute people were cheering and applauding for her from 6:30 - 7:45 of the video. At the timestamp of 7:40 she waved and smiled at the audience. In this speech used more hand gestures than the previous SONAs of 2002 and 2004. The president would raise both hands to put emphasis on certain words. Sometimes only one hand is raised to point to the audience, sometimes some particular group in the audience or a specific person. An example would be when she pointed to House Speaker De Venecia to give him thanks.

According to Russell (2002), emotions are not the only core or source of facial expressions, gestures, and actions of a person. Behavior, sensations, personality, and motives are also influencing factors (Russell, 2002). The aforementioned factors also influence the unconscious. 
In the case of Sigmund Freud, the core of such outward manifestations of the unconscious mind would be the "drives" or desires of a person and neurobiology (Ekstrom, 2004).

Through the actions of President Arroyo in the SONA speeches of 2002, 2004, and 2005, it can be seen and argued how evident the id was in her overall composure in the speeches. The president was still very conscious of what she was saying and doing and proof of it was how quickly she would recover from her Freudian slips. Another proof would be when she would be cut in the middle of what she was saying due to the applause of the people but still manage to remember the last word she said and pick up from where she left off. The remaining SONAs from the years 2006 to 2009 will be further elaborated on to see if she still manifests the id till the last SONA she delivered.

In the 2006 SONA, the meanings behind the gestures of the former Philippine President Gloria Macapagal Arroyo using Sigmund Freud's psychoanalytic theory was again very apparent. The SONA started with the entrance of the former president Gloria Macapagal Arroyo followed by the first gesture that was seen in 3:52, Arroyo upon calling her name stood tall and proud and proceeded to the platform ready to deliver her speech but was called back at 4:42 to her seat to sing the Philippine national anthem, the audience laughed and applauded her mistake which in return she smiled uneasily returning to her seat. This certain action starting with Macapagal standing proudly when her name was called was driven by the 'ego' which governs the reality principle (McLeod, Simply Psychology, 2016). Since Gloria Arroyo came from a well-known family because of its political affiliation, Gloria developed an ego that shows the elated stature of where she came from and her position as the president at that time. The reflection of enthusiasm as she shared the governments' accomplishments to the people. The second action is also driven by ego, the action that is based on the reality principle in which Arroyo became uneasy because of her mistake exposed to the public or the audience.

In 7:01, the researchers observed that Arroyo was not paying attention and engaging in the prayer, she was seen as blinking and looking around which may be seen as a sign of nervousness or uneasiness in the public eye which can be seen as Id driven (McLeod 2016). In 8:07, Arroyo was proudly smiling which may show her eagerness or anticipation to deliver her speech in the public. The speech is assumed to carry positive news which could explain the gestures of Arroyo. In 16:37, Arroyo expressed her boldness of pride in delivering her good news "now we have funds" in this presentation, she discussed the issues that can be solved. She used proud intonation while discussing her agendas in the coming years. In 19:01, Arroyo made a remark that earned applause from the audience with this Arroyo smiled genuinely at the audience, the researchers saw this as a manifestation of Arroyo feeling 'validated' because of her initial reaction to the audience which is driven by ego. In 19:27 Arroyo was laughing because of her own remarks; the researches observe this as a validation as driven by her personal experiences. It can be that she was able to relate or remember a certain incident of memory that happened in the past.

In 32:48, Arroyo showed her proud stance again when she mentioned that the public bidding process and other achievements of the government such as the prioritization of and relocation of illegal settlers and building of houses (40:09), the local project "arms to farms" that deals with agriculture and caravan tractors (56:27), the help of the United Nations with the rebels hiding on the islands of the Philippines (57:14), prioritization of telecommunication technology where she thanked a call center agent for her feedback on the enhancement of BPO companies around Philippines gesturing a hand to her heart to say her thanks (1:04:26). It can be seen in Arroyo's gestures that she is proud and satisfied with the achievements of the government under her reign each of those gestures represents Freud's theory of psychoanalysis, the Id, ego, and superego (McLeod 2016). 
Contrasting the 2007 State of the Nation Address, Arroyo can be seen more determined and serious when it comes to delivering her speeches. She could be seen smiling from time to time especially when discussing the recent achievements, the government was able to perform such as; the accomplishments in agriculture in rural areas, opening of fishing stations, infrastructures, and the Bicol river basin and water shed funding. Arroyo was also seen in 19:25 proudly smiling because of the newly opened Ozamiz airport. After entering the premises and sat on her seat, occasionally the commander whispers something to Arroyo and she would respond quickly to return her attention to the audience. Arroyo also displayed a mannerism in 9:45 as slightly opening her mouth after her speech. This mannerism can also be seen evidently on her 2007 state of the Nation Address. According to Freud this could be because of anxious feeling which is driven by the ego which causes 'reaction formation' (Power of Positivity , 2016). It should be borne in mind that it was during this year that a political storm brew and almost swept Arroyo with allegations of massive cheating and vote shaving in her favor in the 2004 elections which she admitted. The infamous Hello Garci scandal which shall surface in the coming months in 2007 spurred several political rallies and protests that tested not only the mantle of her presidency but more importantly challenged her leadership's legitimacy.

In 11:42, Arroyo displayed sadness when she delivered her speech about the fearless 14 who died because of peace-keeping. In 33:12, Arroyo expressed her happiness when the former chief justice Puno attended the SONA. They may be close or has a personal relationship or are colleagues. In 33:54, Arroyo delivered her speech "inuuna ang bansa, tinatabi ang pulitika" (Country put first, politics set aside) with hardness and determination which the researchers observes as making a point. There may be experiences behind her remarks that caused her to say it with conviction. Lastly, in 42:06 Arroyo, delivered her thoughts on high electricity bill and her plans on how to solve the matter slightly dismay since the public may view this as a negative outcome on her term or displaying of discomfort because of the negativity in the statement.

The State of the Nation Address 2008 has no difference in SONA 2007, Arroyo can be seen as often smiling rather, she is delivering her speech in a more determined and serious way, this can be seen as evolution in the SONA manifesting the seriousness of the situation since this is Arroyo's $8^{\text {th }}$ SONA. In 1:01, Arroyo expressed the importance of the SONA stating that the government was able to achieve "strongest economic growth in our generation" beaming with pride and determination. Comparing to SONA 2006 and 2007 Arroyo showed less bodily gestures besides giving her thanks to her audiences and newly elected officials.

In the last SONA of Arroyo in 2009, the experiences of Gloria Macapagal Arroyo during her last SONA will tell us a gist of why it ended that way using the idea of psychoanalysis of Freud. Sigmund Freud divided the human mind into three parts.

Since it is already the last State of the Nation address of President Gloria Macapagal Arroyo, it can be gleaned that nothing unusual from her actions and vindications are manifested in her speech. The factors in studying the State of Nations Address of the president is not enough to prove that her actions and other mannerisms are unusual and unconscious. The President is also known to be a very professional government official wherein she uses different types or modes of speaking to the public domain. The study presents three events as the basis for the psychoanalysis of the president Gloria Macapagal Arrroyo. 
Firstly, the history that Gloria Macapagal Arroyo had greatly affected her way of governance which is somehow related to the psychoanalytic theory of Freud. Going back to the time where she was the Vice president to later on, becoming the President of the Philippines should be a great factor to explain the psychoanalysis of President Gloria Macapagal Arroyo. President Arroyo became the President of the Republic of the Philippines during the ouster of president Joseph Estrada. It was 2001 when she was proclaimed to be the president of Philippines. It was also in her words that she would never run for the position of the presidency after her term. The opposite happened and she ran for presidency after her term ended in 2004. And this is where she lost her moral ground and the legitimacy of governing country. The "Hello Garci" scandal has greatly affected her; which also affected her governance during his term. President Gloria won the election last 2004 against her rival Fernando Poe Jr. And she won through alleged vote buying. Comparing the idea of psychoanalysis, the psychoanalysis of Freud may be used in explaining the phenomenon of the late president Gloria Macapagal Arroyo (Fajardo, 2013).

The idea of psychoanalysis revolves around the idea of how a person thinks and how it affects their mind on making decisions. It all starts from the idea of having an experience which affects the mind of a person. In the case of President Gloria Macapagal Arroyo and her previous experiences, which is the alleged fraud of her winning in the Presidential elections may have affected her psychoanalytical thinking in the government. There are three manifestations of discrepancies on the way of thinking which relates to Freud's psycho analysis. First, is that her being the Vice president of the Philippines during the term of President Joseph Estrada, in which she was the constitutional successor to the presidency because of the oust of then president It may have affected her way of thinking towards governance. She have said in public that she will not run for presidency after her term; but the opposite happened she ran for President and had an issue in her alleged fraud in the presidential elections of 2004. Secondly, an issue arises in her term during 2004-2010; it is the ZTE-NBN scandal. The scandal started when the government of the Philippines and China had a deal regarding a telecommunication industry. The scandal comprises of loads of different alleged "kickbacks" from the cabinet members of the president; and also the president herself was included. We can see here the manifestation of the president wherein her cabinet members were also part of the one of the biggest alleged "kickback" schemes in the government (Elemia, 2017).

Lastly, the rampant corruption allegations during the term of President Gloria Macapagal Arroyo. According to the SWS as of 2015, there is a consistency rate in corruption from the year 2000 to 2015; though it decreases from year to year starting from 2013.

Figure 1. Extent of Corruption in the Public Sector from 2000-2013

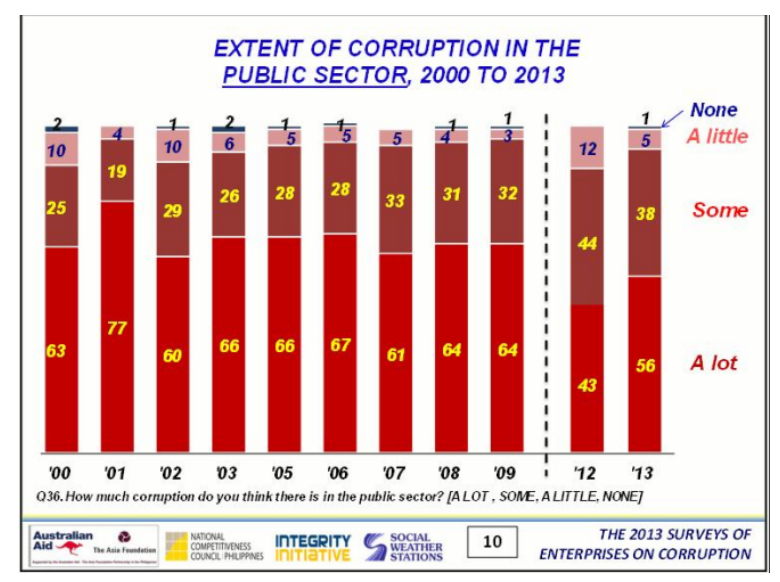


We can see here the manifestations of the psychoanalytical theory of Freud wherein the phenomenon of the past greatly affects the ego of a person. A person become unconscious though he is conscious of the things happening to her surroundings. We can also see a domino effect in the term of President Gloria Macapagal Arroyo. Starting from the alleged legitimacy of her presidency down to her cabinet members, to the local government sectors. It has created a Pandora's box effect in the context of governance during the term of president Gloria Macapagal Arroyo. 
Table 1 SONA Gestures of President Gloria Macapagal Arroyo ( 2002, 2004-2009)

TIME

10:05, 10:25, 10:42, 20:35, 24:01-24:10,

$12: 01,22: 07$

$14: 30$ - 15:35, 16:21, 16:45, 24:01-24:10, 25:00-25:10

$14: 04,16: 45,25: 00-25: 10,27: 47-27: 57$

$20: 27$

TIME

$15: 03,15: 30,19: 08,31: 48,37: 00$,

32:54:00

20:10

$10: 24,39: 00,40: 32,40: 45$,

$14: 34,15: 34,20: 13,24: 30,29: 14,30: 43,33: 31,43: 28,44: 24$,

$44: 45,45: 02$

TIME

$26: 15,30: 47$

$11: 45,16: 45,25: 53,28: 38$,

$6: 30-7: 45,13: 10,25: 53,26: 15$

$7: 40,9: 06,11: 45,13: 10,13: 59,16: 04,16: 50,17: 46,20: 04,21: 19$ $21: 58,22: 24,25: 53,26: 51,26: 54,28: 38,29: 45$
GESTURES SONA 2002

slight nod/shake head

Freudian slip

raise eyebrows

smile

hand gestures

GESTURES SONA 2004

slight nod/shake head

Freudian slip

raise eyebrows

smile

hand gestures

GESTURES SONA 2005

slight nod/shake head

Freudian slip

raise eyebrows

smile

hand gestures

TIME

GESTURES SONA 2006

3:52 Stood and proceeded to the platform

4:24 was called back for the national anthem

4:42 looked at the audience and smiled

7:01 blinking and looking around

8:07 smiled proudly when it was time to deliver her speech

16:37 proud intonation "We now have the funds"

19:01 waved back at the audience for liking her speech

19:27 laughs at her own remark

32:48:00 shows her Proudness "public biding process"

34:50:00 acknowledge and audience by smiling and waving

40:09:00 "housing needs" proud intonation

43:30:00 used hand gestures to emphasize "no political killings"

56:27:00 "arms to farms" hand gestures / proudness

57:14:00 happy with UN 's help with rebels

27:41:00

1:04:26 touched her heart saying thanks

1:08:07 punch gestures "boxing world"

1:08:47 hand gestures / closing remarks / battle for progress

TIME

SONA 2007

6:36 whispering occasionally

9:45 mannerism / slightly opening of the mouth

11:42 sad expression for fearless 14

33:12:00 expressed happiness for Chief justice Puno

33:54:00 delivered speech with determination "unahin and bansa" 
42:06:00 dismay on high electricity bill

\section{TIME GESTURES SONA 2009}

1:21 Welcoming of the new presidency( smiling to serious face)

4:55 Strong Economy of the Philippines (serious)

Explains the million dollar telecommunications development of the Philippines( receives boo from

9:00 crowd, raises hands)

54:00:00 Talks about the democracy of her term( serious face)

55:00:00 growing economy of the Philippines (smiling face)

\section{Psychoanalysis of Former President Benigno Noynoy Aquino III's 2010-2011 SONA}

The first State of the Nation Address of President Benigno Aquino III focused mainly on his proposed solutions towards the anomalies of the past administration. Since it is his first term, it was evident that he tried to form his platforms towards the development of the economy of the Philippines and its sustainability for the coming years to come.

Noynoy Aquino or P-noy as he was later known was the son of Benigno Aquino Jr. also known as Ninoy Aquino. The story of Ninoy Aquino who became a prominent idol of the Filipino people became the center of attention of the Filipino people during the EDSA revolution. The family of the Aquino's became the one of the most powerful families in the Philippines. While after the oust of the late President Marcos, the mother of President Benigno Aquino III became the next president of the Philippines. As a leading opposition force during the EDSA revolution, she accepted the position of being the president of the Philippines. To sum it all up, President Noynoy Aquino III came from a succession of politicians in the Philippines.

Using the idea of Freud, we should start on analyzing the experiences of former President Noynoy Aquino. Coming from a line of well versed politicians, he has greatly improved and was well versed in the skills of governance. That is why in the election of 2010 arises, President Benigno Aquino III soared to the presidency. The pillars of political thought of President Benigno Aquino III shall or may be enhanced since he came from a family of politicians. But using the ideas of Freud in the context of the SONA of 2010-2011, we can see the manifestation of an enhanced ego, id and superego of the President. Starting from scratch, he tends to clean the government from the past administration; which he emphasizes his mean of "Tuwid na daan", or Straight Path, an anti corrupt stance aimed at solving the poverty of the country trough curbing down corruption. Since it is the first years of his term and such anomalies or issues are just to arise, all we can see as a manifestation of the psychoanalysis of Freud is that, his egos are enhanced with the ideas of his political pedigree.

\section{Psychoanalysis of Former President Benigno Noynoy Aquino III's 2012-2015 SONA}

The goal of this part is to find out whether Freud's theory is applicable in the analysis of Former President Noynoy Aquino's SONA through a hermeneutic analysis of what he projects to viewers and listeners of his speeches during the said political event, his body language during the speeches, the frequency of these interpretable bodily movements, as well as the tone and demeanor that he possesses during his speeches.

As mentioned in the previous parts of this reading, the researchers used a hermeneutic analysis on the third, fourth, fifth, and sixth State of the Nation Addresses or SONAs of Former President Benigno Aquino III. The reason for this is to identify the possible meaning behind the body language of Aquino throughout his speeches as well as record the frequency of these 
specific bodily movements during the speech, and if these can be interpreted as data in determining the answer for the goal and purpose of this study.

The data in question are the various movements that Aquino did during his speeches, and are all recorded, compiled and interpreted in order to help answer the questions in this study. In this case, Aquino's body language was recorded in order to be able to interpret his true emotions and feelings during the speeches.

Throughout his speeches, it can be observed that President Aquino has maintained his calmness and had projected a "prim and proper" posture, never losing control of temper or emotion while giving a speech. He does not seem to have a wide array of body language, as while speaking, he is either only clasping his hands or is swaying his body side to side, sometimes he even does a combination of the two. In most of the speeches, he does both almost immediately after he starts his speech, and is consistent throughout all of his speeches, with only very minor stoppage.

It is said that the reason an individual clasps his or her hands in front of the lower abdomen, which is what President Aquino does the most during his speeches, is that the person determines that they are in a position of vulnerability during a situation, but cannot show it and is instead, required to show confidence and respect during the situation (Parvaz, 2015). An individual who is nervous can also be observed to be fidgeting or is constantly moving or doing unnecessary movements when conducting a specific action. This may be an explanation for President Aquino's swaying side-by-side movement when conducting his speeches and it can possibly a form of fidgeting. The dictionary meaning of fidgeting is the action of making small and unnecessary movements, especially of the hands and feet usually caused by nervousness or impatience.

He also displays other body movements which suggest nervousness, and the next most frequent example is by stuttering.

Based on the data gathered from his speeches, the most evident factor for President Aquino is the Superego. The reason for this is because the way he speaks throughout his speeches are uniform and as mentioned before, calm and projects a "prim and proper" aura, which shows that he has control over his emotions and inner desires. He is also very careful in showing his personal desires and preferences, because as a President, he should not let personal preferences and emotions control his decisions and must always do what is most beneficial for his country as. It is this responsibility that drives him to nervousness, as he wants to be the best version of himself for the country, which is identical to the "ideal self" principle of the superego, as the ideal self is what one aims to be at all times, or in other words, one's goals for himself or herself. Actions or behaviors that are not aligned with this ideal self is usually punished by the superego, usually by making an individual feel guilt, and pride in oneself when he or she achieves or upholds actions or behaviors aligned with this ideal self (McLeod, Id, Ego and Superego, 2016).

One can get a lot of information on someone based solely on observing their body language; how they speak, their facial expression while doing something, even the way they move their limbs. It can be said that body language is a form or variant of nonverbal behavior. An estimated 60 to 65 percent of interpersonal communication is conveyed via nonverbal behaviors and many of those nonverbal behaviors are usually unconscious, which would most accurately provide information on an individual's attitude and emotional state (Foley \& Gentile, 2010). 
One alleged instance of a manifestation of the psychoanalysis of President Ninoy Aquino III is the MAMASAPANO siege which concerns the death of the 44 Special Action Force of the Philippines. The MAMASAPANO scandal focused on allegations that government troops in Mindanao fighting the terrorists in the area were forsaken by the administration of the president particularly Ninoy Aquino III. The objective of the mission of the SAF were to abduct a man named Zulkifli Abdhir; which is the most wanted person of the FBI. The problem arose when the government or the military itself lacked communication from the SAF troopers who were in a mission. The connection of this incident is connected to the president itself. The President in the Philippines is known to function also as the commander in chief of the Armed Forces . It is in his powers to have control over missions or he should or should have looked after the mission before starting. In connection to Freud, the ego, Id and superego of the President tends to be unconscious, or must have been conscious but it's just that the president was having different concerns regarding how to run the affairs of the country.

Table 2 SONA Gestures of President Benigno Aquino III 2010-2015z GESTURES 2010 SONA

3:22 Where did the funds go? (serious) hands clasped

6:00 Additional bonus for government officials( angry voice) eyebrows raised

15:00:00 Spoilage of rices in rice warehouses (different intonation)

35:00:00 the Philippines is leading to a "tuwid na daan" (applause) (Smiles)

TIME GESTURES SONA 2011

2:00 WANG WANG ISSUES ( DIFFERENT INTONATIONS)

16:21 agrarian issue of the country (scratches head)

21:05 modern military equipments (applause)

16:05 "Layon Bigyan ang mga nadamay sa martial law" (smiling to serious face)

44:10:00 "Makakasuhan na ang mga nagkonstabahan sa katiwalian" (holds hands)

49:24:00 Serious intonations about how the government seeks to adjust to the " tuwid na daan" (Clasps hands)

Time GESTURES SONA 2012

1:30:09 Clasping of hands in lower abdomen

1:30:17 Swaying side to side

1:30:46 Touches/adjusts glasses

1:35:39 Open palm towards the left

1:36:05 Drinks water

TIME

TIME

GESTURES SONA 2013

0:01 Clasping of hands in lower abdomen

0:03 Swaying side to side

2:06 Drinks water

2:49 Stuttering

1:19 Clasping of hands in lower abdomen

1:21 Swaying side to side

18:26 Stuttering

TIME GESTURES SONA 2015

58:43:00 Clasping of hands in lower abdomen

58:51:00 Swaying side to side 


\section{President Rodrigo Roa Duterte}

The incumbent President Rodrigo Roa Duterte was raised in Davao City, presently known as the Crown Jewel of Mindanao, is the eldest son of Vicente, former governor of the once united Davao province and Soledad, a school teacher and a staunch critic of the Marcos administration. President Duterte's strong, violent, and unorthodox stance against those disobeying the rule and the restrictions provided by law and on those inflicting harm unto other people can be traced back from his upbringing and youth. During his youth, having been raised by a disciplinarian mother, the young Rodrigo Duterte would oftentimes be whipped by their mother due to his bad behavior, which would result in the wearing out of their mother's horsewhip, as narrated by Emmanuel Duterte, the President's brother (Paddock, 2017).

Not only did the President experienced harsh ways of enforcing discipline from his mother but that he also received a beating from Jesuit priests in their hometown's parochial school wherein a cane was used to strike him, according to Emmanuel Duterte (Paddock, 2017). The President also made mention that not only did he receive a beating from a priest he also claimed that he was once molested by one (Paddock, 2017). President Duterte, in his 2015 interview, named Rev. Mark Falvey as his abuser during his freshman year in the Ateneo de Davao High School (Paddock, 2017). In response to the beating done unto him by a priest in his school, the young Rodrigo Duterte once poured ink on a squirt gun and sprayed the ink onto the priest's white cassock, resulting in his immediate expulsion from the institution, as narrated by his siblings (Paddock, 2017).

In his teens, as stated by his brother Emmanuel, the young Rodrigo Duterte would be notorious in engaging in street brawls in their vicinity and had already been carrying a firearm at the age of 15 (Paddock, 2017). His patented rude remarks and expressions were all brought about by his exposure to these types of settings, according to his brother (Paddock, 2017).

Having known the President all his life, Emmanuel Duterte stated that as the young Rodrigo experienced what violence is, may it be at their own home, in his school, and even in their neighborhood, the President would in turn be very angry always. Emmanuel further explained that being a young man who went through all of these pain, it is but normal that one would become angry at all times and have the tendency of not being able to control such emotion (Paddock, 2017). Emmanuel added that with his brother's hardheadedness, "the more you tell him not to do a certain action, the more likely will he do it" (Paddock, 2017).

Before Rodrigo Duterte's ascension into Davao City's top post, the city was once plagued with war and disorder due to the presence of Communist rebels who occupied majority of the area after the overthrow of Marcos' administration. Not only was Davao City devastated by the bloody insurgence from Communist rebels but also from Muslim separatists and various criminal gangs which led to the dubbing of Davao City as the "Murder Capital" of the Philippines (Peel, 2017). According to Heydarian, Davao City before Duterte's stint as mayor can be described as the "Wild West" in the conflict infested island of Mindanao (Peel, 2017). The violence instigated by various armed groups was alarming and gruesome making killings, assassinations, and murders of police personnel a common thing (Paddock, 2017). The entry of President Duterte into the realm of politics came, when in 1986, after the world renowned EDSA People Power Revolution, President Corazon Aquino appointed him as the city's Vice Mayor wherein he served for a year before running for Mayor in 1988 clinching victory "with a pledge to restore law and order" (Peel, 2017). The President had never lost an election since then (Paddock, 2017). 
On top of President Duterte's challenges during his first stint as Davao City's chief executive was on how he could make the people safe from the dangers caused by the armed groups and Communist rebels that violently stormed the city. The former local chief executive didn't view this as an impossible task but instead took this personally and in a resounding fashion. Ever since becoming Davao City's Mayor, President Duterte had embraced and embodied "the image of killer-savior" wherein he'd actually be proud and boast of killing criminals on his own and had said that he'd be happy to slaughter drug addicts (Paddock, 2017).

As violence and the feeling of fear and anxiety enveloped the streets and surroundings of Davao City due to the influx of elements that existed as mentioned above, the newly elected Mayor Rodrigo Duterte at that time knew in himself what to do and what policies and solutions he viewed best to implement so as to make the people feel calm, secured, and at peace. According to Peel (2017), Davao is a city comprised of 1.6 million people and served as Mr.Duterte's blue print to be used in his journey to the presidency. During his time as Mayor of Davao City, the President implemented various measures which helped him enforce the law and make people follow them and to maintain discipline in the city. These were the ff: "a curfew for unescorted minors, a ban on the sale and consumption of alcohol at certain times, a public smoking ban, and fines for noise nuisance" (Peel, 2017). President Duterte strictly led and enforced the laws in Davao wherein a drop in crime rate was achieved but unfortunately resulted in the rise of recorded extra judicial killings which took the lives of petty criminals, drug pushers and users, and street children.

The Philippines is a country with people who don't understand and embody the value of discipline, a country already drowning in the magnitude of the illegal drug problem, and a nation besieged with crime (Lopez, 2015). What President Duterte achieved in Davao as he fought relentlessly against corruption, criminality, and drugs made him stood out in the polls as the Filipino people are desperately hungry for genuine change to occur in the country and would want the Davao experience be felt nationwide (BBC, 2019). President Duterte gained the nation's support because he is not a traditional politician and does not succumb to the criticisms or condemnation of anyone but instead has a long experience in public service and will surely deliver on his promises (Lopez, 2015).

\section{6 - 2019 SONAs and the Freudian Theory in place}

A discussion pertaining to the President's youth and upbringing, his perceived environment, experience in public service, and eventual ascension to the presidency was written above so as to provide background information as to where the President's current behavior, body language and/or mannerisms present in his four previous State of the Nation Address, and his political policies and methods might have originated and also to strengthen the idea that Freud's psychoanalytic theory can be applied.

From his acclaimed book Civilization and its Discontents, Sigmund Freud laid out the three reasons or the sources as to why people experience suffering and pain. These are: 1) "our own body, which is doomed to decay" 2) "the external world" 3) "our relations to other men, which Freud defines as the most painful one" (Perez, 2017). These sources of suffering and pain which Freud carefully came up with can actually be associated to President Duterte's experiences leading to his present behavior, body language, mannerisms, and gestures present in his 2016-2019 SONAs.

The President as mentioned above went through violent and/or harsh methods of disciplining whereas it happened in his "external world" and was done onto his "own body" by people or 
individuals he had "relations" with. The President not only experienced the three sources of suffering and pain which can also attest to the presence and embodiment of Freud's psychoanalytic theory, he did as well saw how in his "external world" (Davao City) bodies of people (victims of armed groups that caused chaos in Davao) were indulged to pain and suffering.

According to McLeod (2018), Freud's psychoanalysis "is a method for treating mental illness and also a theory which explains human behavior," Freud had this belief that the events and experiences a child went through would greatly affect his or her future adult life causing for one's personality to be molded. One example would be is the "anxiety originating from traumatic experiences in a person's past is hidden from consciousness, and may cause problems during adulthood (in the form of neuroses)" (McLeod, 2018). This would then result in an individual's attempt in not expressing wholly his motivation for having such behavior (McLeod, 2018).

In every speaking engagement or important endeavor he has to attend to, President Duterte is someone who does not want to succumb himself to formalities or to any norms deemed acceptable to society. Instead he has the tendency ever since he was elected President to just be who he is and act in a way comfortable for him wherein manifestations of his interesting past and experiences can be seen, making his audience or those listening, watching, and studying him to understand where he's coming from. His four previous State of the Nation Addresses were examples of avenues where the President would surely manifest his unique body language, mannerisms, and gestures.

Being able to establish knowledge as to where these gestures/mannerisms came about, it is but helpful for this research to determine these gestures/mannerisms to be able to interpret them on how they are able to manifest Freud's psychoanalytic theory. During President Duterte's first SONA in 2016 the President delivered his speech and had the tendency of veering away from his prepared speech when explaining an issue/topic or when he's proclaiming a tough warning clearly manifesting Freud's psychoanalytic theory because having been exposed to violence in the past President Duterte had used the same means in carrying out his message even when he's still Mayor.

The President also spoke with emphasis on certain issues especially those pertaining to drugs and would occasionally scratch his head clearly showing frustration or anger with regard to the issue he raised making it another manifestation of Freud's psychoanalysis because as mentioned above past experiences and events create an impact on the person and could play a role in the transformation of his personality. In order to display control and a firm grip on power the President held on to the podium with his two hands almost all throughout the speech showcasing that he's the one in charge.

The second SONA of President Duterte was his longest so far this was when he veered away from his prepared speech in almost the entirety of the SONA and grabbed the opportunity in voicing out his disappointment and anger to his critics. This is a manifestation of Freud's psychoanalysis because this goes to show that the President would ultimately do anything even though he was already prevented from doing so and that no one can stop him. Basically solidifying his brother's narration that the President due to his exposure to violence even during his formative years resulted in him having temper issues and can make it hard for him to control his emotions. 
Contrary to his SONA 2017, last year's SONA was the shortest one delivered by President Duterte so far. Here, he decided to stick with his already prepared speech and did not veer away much. However, being the person that he is, the President's patented gestures/mannerisms still showed during his third SONA. He still uttered words with strong emphasis, raised his hands and lightly pounded the podium with a closed fist because of frustration.

To sum up, President Duterte was consistent in showcasing his gestures/mannerisms in all four of his State of the Nation Addresses. The President's gesture/mannerism that stood out was his tough talking style of uttering words with strong emphasis clearly showing his anger and frustrations particularly on issues pertaining to criminality, corruption, and illegal drugs, which are the three main problems his presidency would want to solve. This goes to show that the President's past experiences prior to his presidency which caused him to absorb and profess anger through the years clearly manifests Freud's psychoanalytic theory. The last SONA held July of this year (2019) clearly shows an exasperated, tired and visibly frustrated Duterte 15:09; 17:07; 19:53. This exasperation emanates from the fact that despite his efforts to curb down corruption and the drug menace, the same problems still exists.

\section{Table 3 SONA Gestures of President Rodrigo Roa Duterte}

TIME
$0: 20$
$0: 24-0: 51$
$2: 34-3: 48$
$5: 55,7: 00-8: 19,10: 31,12: 58-13: 03,14: 44-14: 50,15: 58,18: 08-18: 58$,
$20: 58-21: 00,23: 50-23: 56,24: 17-24: 29,27: 42,29: 27,38: 30,42: 45$
9:31, 19:38
TIME
$4: 40$
$5: 27$

11:09

$11: 50-12: 46$

$18: 05,24: 11$ - 24:12, 27:07, 29:01, 31:10, 31:33, 31:51, 32:27, 32:54, 35:46, $36: 24$

TIME

4:55:00

6:36, 15:16

$12: 57,27: 53,31: 30,35: 37,38: 00$

$15: 18,18: 44$

19:04-19:07
GESTURES SONA 2016

slight nod/shake head

Freudian slip

raise eyebrows

Rising tone of voice, closed

fists

hand gestures/ closed fists

GESTURES SONA 2017

slight nod/shake head

Freudian slip

raise eyebrows

smile

hand gestures/ closed fists / hand to the chest

GESTURES SONA 2018

slight nod/shake head

Freudian slip

raise eyebrows

smile

hand gestures

\section{CONCLUSIONS AND RECOMMENDATIONS}

In summary, the study anchored itself mainly on a Qualitative analysis of the Freudian elements as seen in the gestures, actions, bodily movements of selected State of Nation Addresses delivered by Philippine presidents.

Using hermeneutics as the primary research technique employed in the study, the researchers were able to analyze the presence of Freud's psychoanalytic concepts in the said speeches and the way they were delivered. In addition, the analysis also included how the presence of 
Freudian components in these SONA's, may have affected their leadership styles and decisionmaking pertinent to their respective regimes.

The study yielded the following conclusions;

1. The hermeneutic analysis revealed that Freudian elements are present in all three Presidents' SONA.

2. The gestures and movements of the Presidents in the SONA reflect the sentiments and issues of the time the SONA was delivered. It demonstrated that guided inferences can be made with the background, and current political sentiments on issues using these gestures and body movements of the nation's leaders. This can be seen in the gestures of Pres. Arroyo as she boasted of the accomplishments of her "Strong Republic", of the laid back, relaxed vernacular undertones of the "Straight Path" of Pres. Aquino and the strong message carried out in Pres. Duterte's relentless fight against corruption and illegal drugs. The gestures and body movements also demonstrate the personality of each chief executive which in turn is radiated in their leadership styles.

3. Of the three presidents that were analyzed, in terms of gestures and body movements, President Duterte shows the greater tendency to be bold and decisive based on the tenacity of his actions and gestures while making his speech.

3. All of the three presidents carry the psychoanalytic elements of Freud namely, the Id, the Ego and Superego. Freudian slips are also contained in the SONAs of all the three presidents.

4. Non verbal communication is important in understanding the political motivations, sentiments and considerations of political actors as these actions manifest dedication and sincerity.

5. Gestures and body movements reveal a considerable degree of meaning behind speeches such as the State of the Nation Address.

\section{Recommendations}

On a more practical level, the research recommends that the public be more analytic especially in listening to future SONAs to be delivered. Indeed, the message is contained in the messenger and that the people must understand that even in seemingly simple speeches like the SONA, discernment and a deeper appraisal of the manner by which it was delivered and not just the contents matter greatly.

However, more research is definitely required with regards to this topic, even though the data proved to be limited, future researchers may find more intriguing and significant factors in the data which can be gathered by analyzing the contents of the speeches of the former presidents, which may help in gaining better understanding of how one's mind works especially in the realm of Politics. Future researchers may do this by applying different analyses and theories in order to achieve varied results which may be useful in the fields of political science and psychology, as there may be more appropriate and responsive theories in both fields that can be used in order to gain more data and deeper meaning in this study.

\section{References:}

Adolphs, R. (2002). Recognizing Emotion from Facial Expressions: Psychological and Neurological Mechanisms. Behavioral and Cognitive Neuroscience Reviews, 1(1), 21-62.doi:10.1177/1534582302001001003

Bargh, J. A., \& Morsella, E. (2008). The Unconscious Mind. Perspectives on Psychological Science, 3(1), 7379.doi:10.1111/j.1745-6916.2008.00064.x

BBC. (2019). Profile: Duterte the controversial 'strongman' of the Philippines. Retrieved from: https://www.bbc.com/news/world-36659258.

Bondi , L. (2007). Psychoanalytic Theory. United Kingdom: University of Edinburgh. 
Sy, A. N., Yson, M. L. B., Gavino, N., Leon, M. W. D., Ocampo, J., \& Calilung, F. C. (2019). When Politics is more than Words: A Hermeneutic Analysis of Freudian Psychoanalytic Elements among selected Philippine Presidential State of the Nation Addresses (SONA). Advances in Social Sciences Research Journal, 6(10) 384-402.

Ekman, P. (1992). Facial Expressions of Emotion: New Findings, New Questions. Psychological Science, 3(1), 3438.doi:10.1111/j.1467-9280.1992.tb00253.x

Ekstrom, S. R. (2004). The mind beyond our immediate awareness: Freudian, Jungian, and cognitive models of the unconscious. Journal of Analytical Psychology, 49(5), 657-682. doi:10.1111/j.0021-8774.2004.00494.x

Elemia, C. (2017, October 5). De Lima seeks probe into alleged corruption in DICT project.

Fajardo, F. (2013). A hunger for power and a thirst for wealth: Establishing a link between early political corruption and the pork barrel system. Journal of South Asian Studies, 55-65.

Foley, G. N., \& Gentile, J. P. (2010). Nonverbal Communication in Psychotherapy. Psychiatry (Edgemont) 2010;7(6):38-44, 38-44.

Lopez, L. (2015). Why our country needs to make Duterte president. Retrieved from: https://opinion.inquirer.net/86793/why-our-country-needs-to-make-duterte-president.

McLeod, S. (2016, February 5). Id, Ego and Superego. Retrieved from SimplyPsychology: https://www.simplypsychology.org/psyche.html

McLeod, S. (2016). Simply Psychology. Retrieved from https://www.simplypsychology.org/psyche.html

McLeod, S (2018). What are the most interesting ideas of Sigmund Freud? Retrieved from:https://www.simplypsychology.org/Sigmund-Freud.html.

Paddock, R. (2017). Becoming Duterte: The Making of a Philippine Strongman. Retrieved from: https://www.nytimes.com/2017/03/21/world/asia/rodrigo-duterte-philippines-president-strongman.html

Paz, H. (2015, May). Body language: Clenching and clasping of the hands. Retrieved from PsychMechanics: https://www.psychmechanics.com/2015/05/body-language-clenching-and-clasping-of.html

Peel, M. (2017). Drug and Death in Davao: The Making of Rodrigo Duterte. Retrieved from: https://www.ft.com/content/9d6225dc-e805-11e6-967b-c88452263daf.

Perez, A (2017). Civilization and its Discontents. Retrieved from: http://www.book-success.com/civilizationdiscontents-sigmund-freud-2/.

Power of Positivity . (2016, February 02). Retrieved July 2019, from https://www.powerofpositivity.com/10 things-sigmund-freud-taught-us-about-our-thoughts/

ussell, J. A. (2002). The psychology of facial expression. Cambridge: Cambridge Univ. Press.

Solms, M. (2004). Freud Returns. Scientific American, 290(5), 82-89. Retrieved from http://www.jstor.org/stable/26047718

The Famous People. (n.d.). Retrieved July 20, 2019, from https://www.thefamouspeople.com/profiles/gloriamacapagal-arroyo-6994.php 